\section{Michigan Technological \begin{tabular}{lll}
\hline 1 & 8 & University \\
\end{tabular}}

Michigan Technological University Digital Commons @ Michigan Tech

4-5-2016

\title{
Field tests of cement fly-ash steel-slag pile composite foundation
}

Bing Zhang

China University of Geoscience Beijing

Shuai Cui

China University of Geoscience Beijing

Follow this and additional works at: https://digitalcommons.mtu.edu/cee-fp

Part of the Civil and Environmental Engineering Commons

\section{Recommended Citation}

Zhang, B., \& Cui, S. (2016). Field tests of cement fly-ash steel-slag pile composite foundation. Journal of Testing and Evaluation, 45(3), 860-872. http://dx.doi.org/10.1520/JTE20140422

Retrieved from: https://digitalcommons.mtu.edu/cee-fp/45

Follow this and additional works at: https://digitalcommons.mtu.edu/cee-fp

Part of the Civil and Environmental Engineering Commons 
doi:10.1520/JTE20140422 / Vol.45 / No.3 / May 2017 / available online at www.astm.org

Manuscript received April 19, 2014; accepted for publication February 2, 2016; published online April 5, 2016.

${ }^{1}$ Dept. of Civil Engineering, China Univ. of Geosciences, Beijing, China (Corresponding author), e-mail: sc_zhb@cugb.edu.cn

2 Dept. of Civil Engineering, China Univ. of Geosciences, Beijing, China

3 Dept. of Civil and Environmental Engineering, Michigan Technological Univ., Houghton, MI 49931
Bin Zhang, ${ }^{1}$ Shuai Cui, ${ }^{2}$ Zhen Liu, ${ }^{3}$ and Fan Feng ${ }^{2}$

\section{Field Tests of Cement Fly-Ash Steel-Slag Pile Composite Foundation}

\section{Reference}

Zhang, B., Cui, S., Liu, Z., and Feng, F., "Field Tests of Cement Fly-Ash Steel-Slag Pile Composite Foundation," Journal of Testing and Evaluation, Vol. 45, No. 3, 2017, pp. 860-872, http://dx.doi.org/ 10.1520/JTE20140422. ISSN 0090-3973

\section{ABSTRACT}

Steel slag is one of the main waste materials in the steelmaking process. As a result, a tremendous amount of steel slag is produced and deposited into storing yards every year. Recycling of the abandoned steel slag is of great environmental and economic value. This study investigates the usage of steel-slag concrete with fly ash as a kind of composite foundation pile material, which can be applied to multi-pile composition foundations for ground improvement involving different pile types. The micromorphology of the concrete, which uses steel slag as aggregate, is analyzed using scanning electron microscopy (SEM). The bearing characteristics of cement fly-ash steel-slag pile (CFS pile) composite foundations are investigated via field load tests, including settlement of the foundation base, horizontal displacement at different depths, distribution of vertical stress increase of the composite foundation, and stress increase of the soil around the pile hole. In addition, the effect of soil squeezing caused by the construction of a CFS pile is studied. To accomplish this, the variation in the increase in stress of the foundation at different distances in the horizontal direction is measured. The results suggest that the usage of steel slag as an aggregate can effectively satisfy the strength requirement of the pile. CFS pile composite foundations have the advantages of high bearing capacity, small settlement deformation, and limited horizontal deformation. This study demonstrates the potential usage of steel slag as aggregate in pile composite foundations, which can bring significant economic and environmental benefits.

\section{Keywords}

cement fly-ash steel-slag pile, microstructure, composite foundation, bearing characteristics, field load test, soil squeezing effect 


\section{Introduction}

Steel slag is a common hazardous material produced by the steel industry. It accounts for $15 \%-20 \%$ of iron output [1]. The large quantities of steel slag produced and its potential impact on the environment have attracted increasing attention. Steel slag has been widely reused for various purposes throughout the world [2]. Slag has been used as a phosphatic fertilizer and in water and wastewater purification [3]. Owing to its sorptive characteristics, Dimitrova and Mehanjiev [4] considered steel slag as a low-cost adsorbent used in water and wastewater treatment. Additionally, owing to its high strength and durability, steel slag can be used as an aggregate not only in surface layers of pavement but also in unbound bases and subbases $[5,6]$. The replacement of coarse natural aggregate with steel-slag aggregate can fully satisfy the requirements of asphalt concrete $[7,8]$. In addition to its proven benefits in cement quality, such as low heat of hydration, high long-term strength, controllable alkali-silica reaction, resistance to acid, and better durability gained by the addition of granulated slag, slag is considered as a cost-saving measure in the cement industry. In developing countries, such as China, the utilization percentage is lower, which is approximately $50 \%-60 \%$ [9]. Although slag has also been reused in the construction, building materials and cement industries in China, the compositions and performance of steel slag require further research to provide a theoretical basis for utilization [10-12].

Steel slag mainly contains dicalcium silicate $\left(\mathrm{C}_{2} \mathrm{~S}\right)$, tricalcium silicate $\left(\mathrm{C}_{3} \mathrm{~S}\right)$, and tetracalcium aluminoferrite $\left(\mathrm{C}_{4} \mathrm{AF}\right)$ [13]. Cement fly-ash gravel (CFG) pile composite foundations have been widely applied in soft subsoil treatment in highways, railways, and building engineering [14,15]. Compared with gravel in CFG, steel slag is substituted for gravel as aggregate in CFS piles. In addition to the strength of steel slag itself, the pozzolanic reactions contribute further to the pile strength buildup, whereas CFG piles have no such chemical composition. The use of steel-slag aggregate in concrete has been reported as beneficial, particularly in areas where high-quality aggregates are not easily available or must be hauled from long distances. Maslehuddin et al. [16] indicated that the physical properties and durability characteristics of steel-slag cement concretes were better than those of crushed limestone aggregate concrete. Huang et al. [17] illustrated the mechanism and testing method of steel-slag piles in improving the collapsible loess foundation of a factory in China. Zhou and Du [18] carried out field tests to analyze the bearing capacity of a CFS pile adopted in manmade fill. Using steel slag as aggregate can reduce the demand for gravel and, thus, reduce the cost whereas increasing the utilization ratios of steel slag and reducing pollution.

This study investigates the beneficial use of steel slag in cement fly-ash steel-slag piles (CFS piles) in composite foundations. Steel-slag concrete possesses low early strength, which is much improved in late stages. Therefore, CFS piles can obtain binding strength after the setting of the concrete. A CFS pile together with soil and cushion compose a composite foundation [19]. In the CFS pile forming process, the pile will squash the surrounding soils and make them denser. Additionally, CFS piles have ion exchange reactions and pozzolanic reactions with surrounding soils. All mechanisms mentioned above can effectively improve the physical and mechanical properties of surrounding soils and consequently enhance the bearing capacity of the foundation [20]. Therefore, CFS pile composite foundations can be used in the treatment of collapsible loess, soft clay, loose fill, and other problematic soils. Although CFS pile composite foundations have been used in some engineering projects, in which engineering requirements were satisfied by their bearing capacity, the mechanism of the pile-soil interaction has never been investigated. This work studies the micromechanism of CFS piles for strength via laboratory tests and the bearing characteristics of CFS pile composite foundations via field tests. Finally, the effect of soil squeezing during the construction of CFS piles was also studied.

\section{Materials and Methodologies}

\section{MATERIALS AND SPECIMENS}

The CFS pile is a new type of pile built with steel-slag concrete. The steel-slag concrete used in this study is a low-strength concrete composed of cement, recycled steel slag, fly ash, and a certain amount of water [21]. The slag used in the study came from pig iron refining with Linz-Donawitz (LD) converters at Wuhan Iron and Steel Corporation in Hubei, China. The chemical components of the steel-slag samples were typical of this type of material in China [22,23]. The chemical compositions of the tested fly ash and steel slag are shown in Table 1. The grain size distributions for the tested steel slag and fly ash are shown in Fig. 1. The steel-slag aggregate has a mean particle size of approximately $6 \mathrm{~mm}$, whereas the steel-slag powder is much finer with a mean particle size of approximately $0.5 \mathrm{~mm}, 25 \%$ of which pass through a No. $200(75-\mu \mathrm{m})$ sieve. The used fly

TABLE 1 Chemical compositions of the tested steel slag and fly ash.

\begin{tabular}{llccccccc}
\hline Chemical Element & $\mathrm{SiO}_{2}$ & $\mathrm{Al}_{2} \mathrm{O}_{3}$ & $\mathrm{Fe}_{2} \mathrm{O}_{3}$ & $\mathrm{TiO}_{2}$ & $\mathrm{MgO}$ & $\mathrm{CaO}$ & $\mathrm{SO}_{3}$ & Loss on Ignition \\
\hline Steel slag & 17.5 & 2.68 & 25.1 & 0.74 & 9.16 & 40.3 & 0.07 & 1.74 \\
Fly ash & 32.34 & 20.12 & 2.65 & 0.83 & 0.96 & 6.5 & 0.4 & 34.26 \\
\hline
\end{tabular}


FIG. 1 Grain size distributions for the tested steel slag and fly ash.

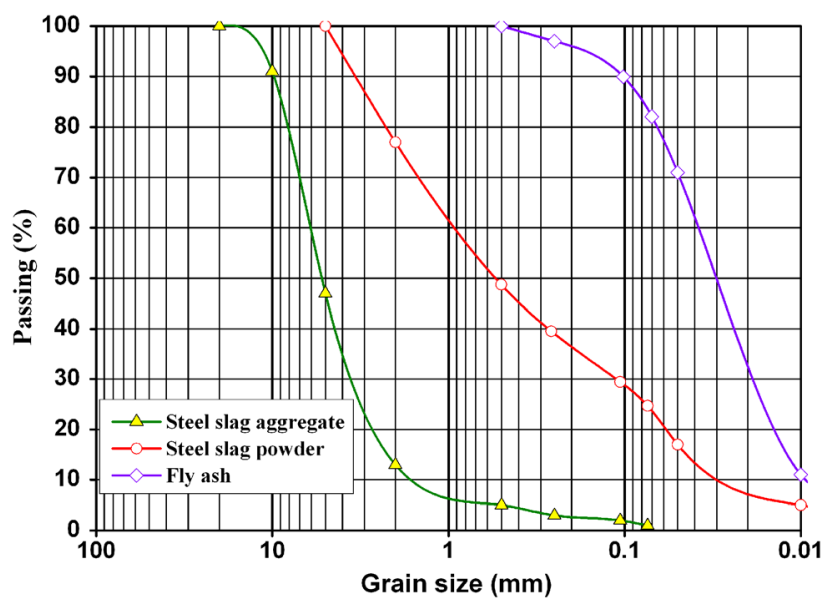

ash is classified as class F fly ash, whose particles have a mean size of approximately $20 \mu \mathrm{m}$ and an $85 \%$ passage rate through a No. $200(75-\mu \mathrm{m})$ sieve. Fixed quantities of steel-slag aggregate and powder, i.e., $1135 \mathrm{~kg} / \mathrm{m}^{3}$ and $700 \mathrm{~kg} / \mathrm{m}^{3}$, respectively, were used in the manufacturing of the concrete samples. The quantities of the cement and fly ash were $265 \mathrm{~kg} / \mathrm{m}^{3}$ and $175 \mathrm{~kg} / \mathrm{m}^{3}$, respectively. A constant water-cement ratio of 0.45 was adopted in the preparation of the concrete mixtures. Cube specimens $(150 \mathrm{~mm} \times 150 \mathrm{~mm})$ were cast in steel molds, and a table vibrator was adequate for compaction. Demolding was carried out after $24 \mathrm{~h}$ of casting, and curing was effected by storing the specimens under water. After curing and surface drying, the compressive strength of the concrete cubes was determined in accordance with Chinese standards GB/T 50107-2010 [24].

\section{MICROSTRUCTURAL ANALYSIS}

SEM analyses were carried out to examine the morphology of the hydration products and the interfacial transition zone between the cement paste and aggregate in the concrete samples cured for 7 days and 28 days $[25,26]$. Information regarding the phase arrangement inside the material structure was essential because some phases such as gel C-S-H phase strengthen the composite structure and improve its fracture toughness [27-29]. Conversely, other phases such as portlandite crystals (CH) can cause significant weakening [30,31]. The cement hydration products had a great influence on the macroscopic mechanical properties of the concrete [32]. In addition, the interfacial transition zone (ITZ) was a weak area in the internal structure of the concrete. The microstructure of the ITZ had crucial effects on the macro-mechanical performance [33]. The concrete samples for SEM analysis were dried at $105^{\circ} \mathrm{C}$. The surfaces were coated with gold in a vacuum evaporator. The samples were examined via scanning electron microscopy (SEM) to observe their morphological features.
TABLE 2 Basic data of the pile for the composite foundation.

\begin{tabular}{lcccc}
\hline Zone & $\begin{array}{c}\text { Pile } \\
\text { Diameter }(\mathrm{mm})\end{array}$ & $\begin{array}{c}\text { Pile } \\
\text { Length }(\mathrm{m})\end{array}$ & $\begin{array}{c}\text { Distance } \\
(\mathrm{mm})\end{array}$ & $\begin{array}{c}\text { Replacement } \\
\text { Ratio (\%) }\end{array}$ \\
\hline A & 450 & 8.30 & 1300 & 10.90 \\
B & 450 & 6.80 & 1400 & 9.40 \\
\hline
\end{tabular}

\section{TEST FOR PILE-SOIL STRESS RATIO}

The ratio of the stress at the top of a pile to the stress of the soil around the pile affects the bearing capacity and deformation of the composite foundation. The variation of this pile-soil stress ratio is the key factor in designing economical and mechanically satisfactory composite foundations [34]. CFS pile composite foundations were applied to the plant building of a hot-rolled strip of the Wuhan Iron and Steel Corporation (Wuhan, China). The plant building, used for depositing billets, was single-layer frame structure, and the type of foundation used for the building was single-pile foundation under columns. The load of the billets was $240 \mathrm{kPa}$. The allowable settlement of the foundation was $120 \mathrm{~mm}$. As shown in the stratigraphic profile below, the strata consist of one layer of plain fill and two different layers of silty clay. The groundwater level is $1.8 \mathrm{~m}$ beneath the ground. The bearing capacity of the natural foundation was only $100 \mathrm{kPa}$. The CFS piles used for ground improvement were studied in situ to determine the pile-soil stress ratio. Two types of pile arrangements were used in two separate zones. An equilateral triangle arrangement was used in zone $\mathrm{A}$, whereas a square layout was adopted in zone B. The basic properties of the pile for the composite foundations are shown in Table 2.

As shown in Fig. 2, a circular bearing plate with a diameter of $1060 \mathrm{~mm}$ was used for the static loading test in accordance with Chinese Standard (JGJ79-2012) [35]. The loading was increased by $50 \mathrm{kPa}$ in each step of the stage loading process with an initial loading of $50 \mathrm{kPa}$. After each imposing load process, we measured and recorded the displacement every $10 \mathrm{~min}$ during the first $30 \mathrm{~min}$ and every $15 \mathrm{~min}$ in the following $30 \mathrm{~min}$. We then measured and recorded the displacement every

FIG. 2 Locations of earth pressure sensors.
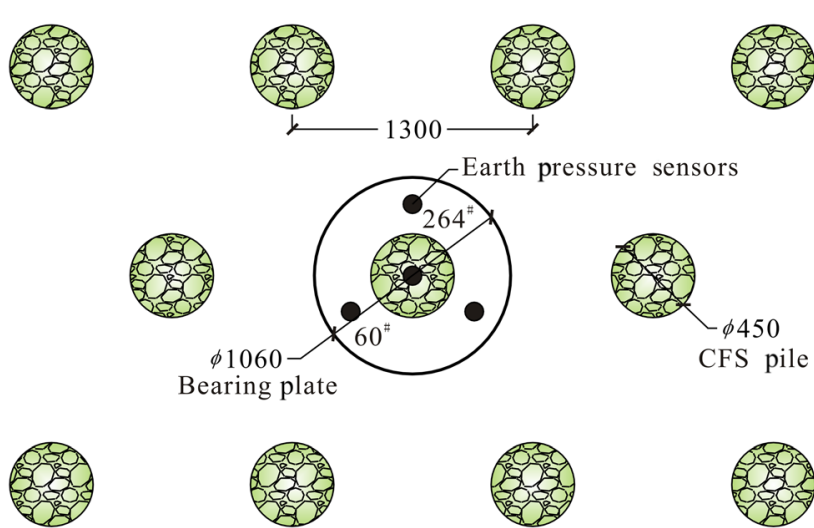

Bearing plate CFS pile
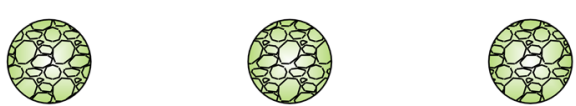
FIG. 3 Schematic of device arrangement in field load test: (a) layout plan, and (b) profile map.

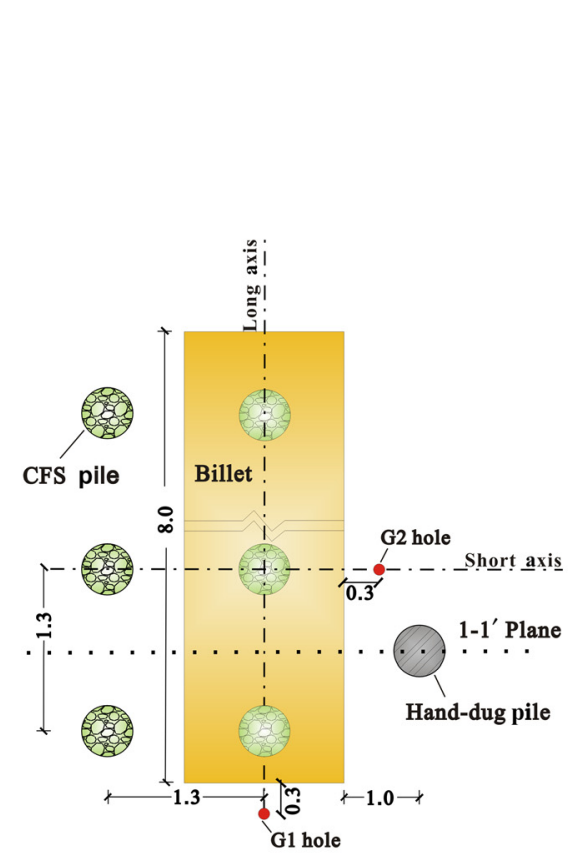

(a)

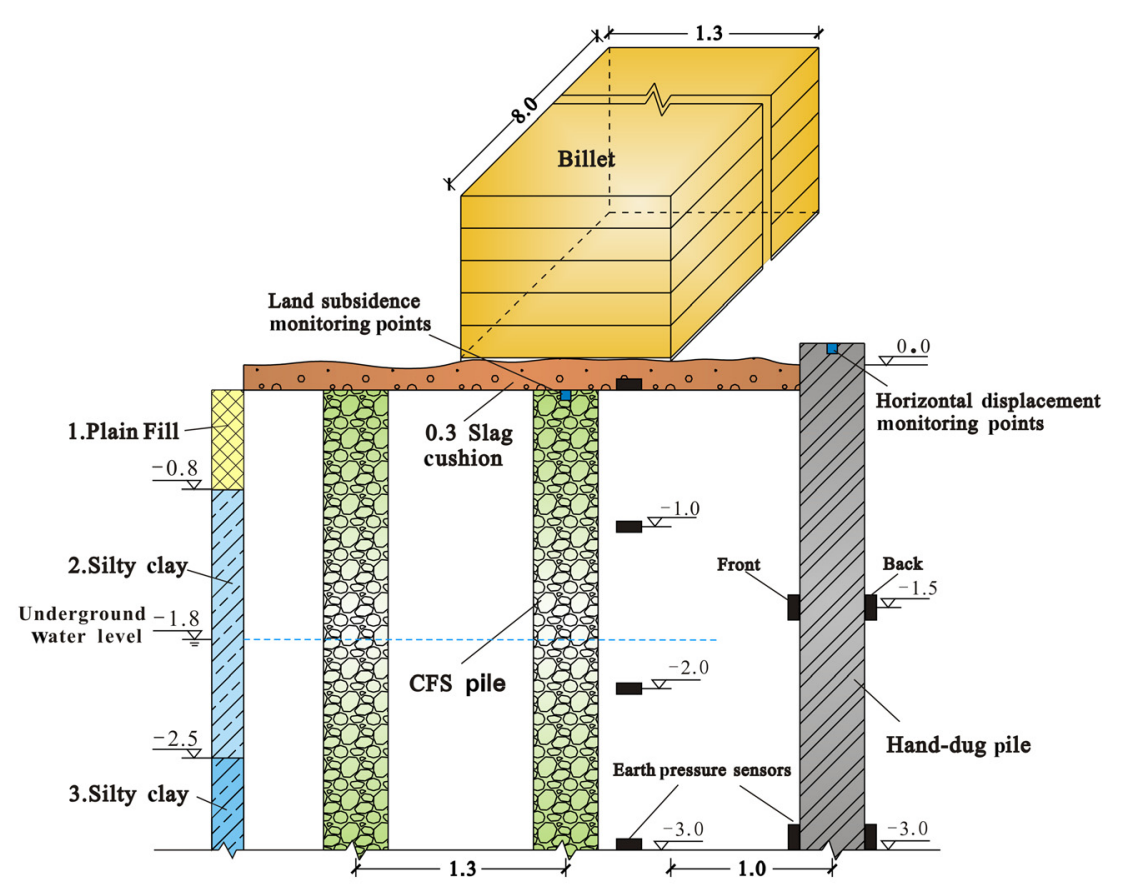

(b)
$30 \mathrm{~min}$. The measurement process was not concluded until the displacement was less than $0.1 \mathrm{~mm}$ in two successive measurements. Earth pressure cells were buried in the soil near the top of the pile and in the soil between piles. These pressure sensors were used to monitor the variation of the stresses under the load from the bearing plate.

\section{FIELD LOADING TEST OF COMPOSITE FOUNDATION}

To investigate the bearing characteristics of the CFS pile composite foundation during operation, field loading tests were conducted before the construction of the factory building. CFS piles were placed with a square. The pile spacing was $1.2 \mathrm{~m} \times 1.2 \mathrm{~m}$, and a single pile had an effective length of $8.3 \mathrm{~m}$ (Fig. 3). The testing results will provide references for engineering design and theory development. The loading test used stacked billet loading with a contact area of $8.0 \mathrm{~m} \times 1.30 \mathrm{~m}$. The foundation pressure caused by 250 tons (actual load applied) of billet was $240 \mathrm{kPa}$, which is equivalent to the design value of the bearing capacity of the composite foundation. The settlement of the basement was measured by land subsidence monitoring points. Settlement observation datum piles were set at the short side of the billet. The datum beam was fixed on the datum piles to record the settlement of the base. The settlement of the basement was recorded by dial indicators installed on the datum piles. The observation holes for horizontal displacement were arranged along the long axis (G1 hole) and short axis (G2 hole) of the billet carrier $0.3 \mathrm{~m}$ from the corresponding edge of the billet (Fig. 3(a)). Inclinometers were adopted to measure the horizontal displacement at different depths of the composite foundation under billet loads. A hand-dug pile was also constructed at $1 \mathrm{~m}$ from the edge of the billet. The hand-dug pile was used to simulate the foundations of the factory to be built. The pile foundation was uplifted by the superimposed pressure of the soil. The horizontal displacement of the top of the pile was measured by horizontal displacement monitoring points. Twenty-four earth pressure sensors were installed with a $1.5-\mathrm{m}$ spacing before and after the hand-dug pile to record the increase in horizontal stress in the front and backside of the hand-dug pile. The increase in the vertical stress of the soil at different depths was studied as well.

\section{EFFECT OF SOIL SQUEEZING DURING CFS PILE CONSTRUCTION}

CFS piles produce a squeezing effect on the surrounding soil during the tamping process. Because CFS piles are constructed by displacement method, and soil in the original position of the piles was squeezed into the space around the piles by the double pipe hammering method. Besides, it also needs time to reach the designed strength of piles and play their role effectively. Therefore, excessive horizontal stress induced by the squeezing effect in the soil may destroy the completeness of the adjacent pile, thus reducing the bearing capacity of the pile. Thus, reasonable pile spacing is the main factor in avoiding these adverse effects. It is important to study the effect of soil squeezing during the tamping process to analyze issues such as the influence range of the stress increase and the surface upheaval. To study 
FIG. 4 Layout of earth pressure sensors.

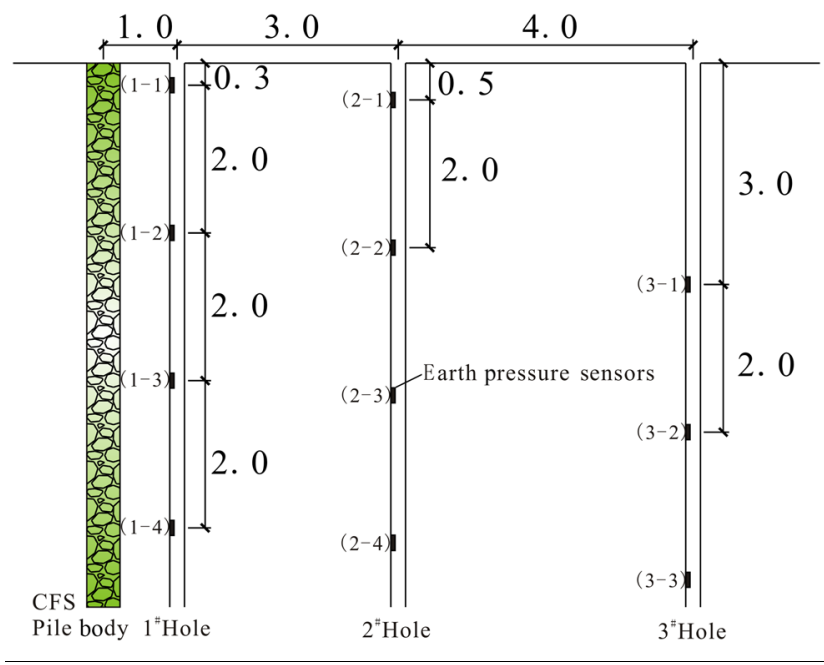

the variation of the stress increase in the horizontal direction, a pile was monitored. Earth pressure sensors were buried at $1 \mathrm{~m}$, $4 \mathrm{~m}$, and $8 \mathrm{~m}$ from the pile (Fig. 4), and stress increase was recorded automatically with a computer during the tamping process. Each pressure value in the "forming tamping process" and "backfill tamping process" of the pile was recorded. Moreover, monitoring points were designed to measure the surface uplift height caused by the construction (Fig. 5). The degree of surface upheaval after pile construction was measured with a digital level.

\section{Results and Discussions}

\section{MORPHOLOGY BY SCANNING ELECTRON MICROSCOPY}

Fig. 6 shows SEM micrographs of the steel slag and fly ash used in the pile materials. The steel slag is mainly composed of clusters of particles with irregular shapes, whereas the fly-ash particles exhibit approximately spherical shapes. The microstructural analysis can help us analyze the strength development of the concrete cured for 7 days and 28 days. The compressive strength of the cube specimens after 7 days and 28 days of curing are 9.2 $\mathrm{MPa}$ and $19.5 \mathrm{MPa}$, respectively. The SEM micrographs obtained from these specimens are shown in Figs. 7a-7d. Hydration of calcium silicates mainly produces calcium silicate hydrate (C-S-H), which accounts for the main strength of concrete. However, $\mathrm{CH}$ contributes little to the strength of the concrete [28]. As seen, much of the surface features cemented fine particles, which are labeled "C-S-H" in Fig. 7a [31]. Some crystals of $\mathrm{CH}$, the product of cement hydration and the reactants of the pozzolanic reaction, have a laminar morphology. It is seen that there are few $\mathrm{CH}$ crystals or pseudocrystals near the edges of the aggregates in Fig. $\mathbf{7 b}$. $\mathrm{CH}$ plates pack in the structure of the C-S-H phases, which may indicate that reactions of portlandite affect the transition into the C-S-H phase. With a high content of active silica in steel slag and fly ash, these particles react with $\mathrm{CH}$ to form C-S-H gels and consequently accelerate the hydration process. The pozzolanic reactions contribute more to strengthen the buildup. Fig. 7b shows that the dense microstructures are the result of an intimate intermingling of amorphous $\mathrm{CH}$ and C-S-H gel.

The bond near the interfacial transition zone (ITZ) can be clearly identified in Fig. 7c. The cement matrix in the neighboring area of the aggregate is porous. In contrast, Fig. 7d shows that the paste combined with the aggregate tightly, making it difficult to distinguish the interface. In addition, no microcracking is found on the aggregate boundaries. It is indicated that a better bonding between the hydration products and the surface of the aggregates is an important factor in maintaining good macroscopic mechanical properties. Comparisons of these micrographs show the variation of the microstructure of specimens during the hydration process.

\section{PROPERTIES OF FOUNDATION SOIL LAYERS AFTER CONSTRUCTION}

The physical and mechanical properties of soil layers before and after construction are shown in Table 3.

Comparisons between the properties before and after consolidation demonstrate the increased strength during the construction of the composite pile foundation. After consolidation, the void ratio of the soil layers decreased by $10 \%$. In the meantime, the compression modulus and standard penetration number significantly increase. These increases indicate that the foundation treatment results in a better compaction of soil layers. Shear strength indexes such as cohesion and internal friction angle also demonstrate improvement after the foundation treatment. In summary, the strength of soil between CFS piles has been improved.

\section{TEST RESULTS OF PILE-SOIL STRESS RATIO}

Representative piles in zone A and zone B are selected for single-pile composite foundation load testing.

FIG. 5

Layout of monitoring points.

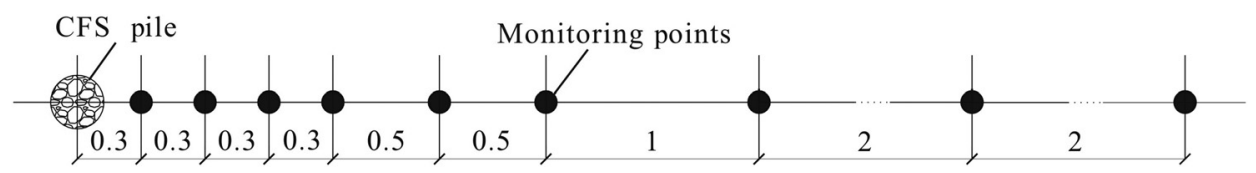


FIG. 6

SEM micrographs of steel slag and fly ash: (a) steel slag, and (b) fly ash. (a)

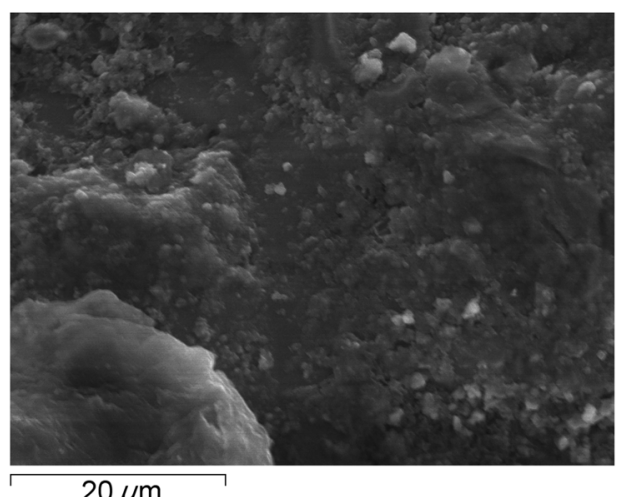

(b)

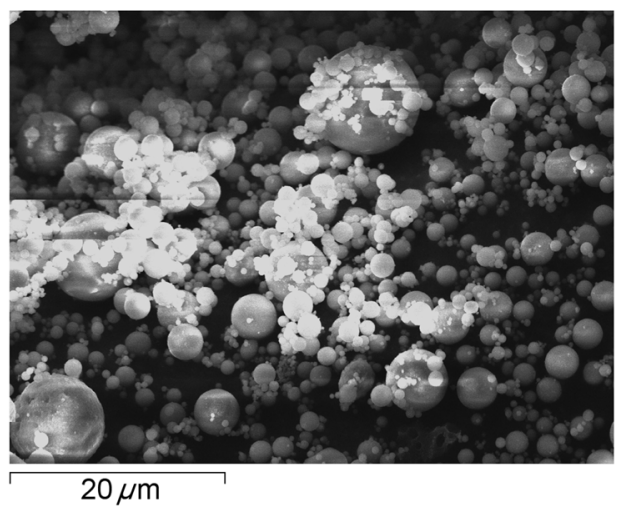

\section{Bearing Capacity of Piles and Soil}

As shown in Fig. 8, the result of the loading test indicates that the bearing capacity of the single-pile composite foundation is approximately $320 \mathrm{kPa}$ and the soil between piles is approximately $100 \mathrm{kPa}$. The result indicates that the CFS pile composite foundation is an effective method for improving the bearing capacity of underlying soft ground.
Variation of Pile-Soil Stress Ratio With Loading

Owing to the cushion effect, both the pile and the soil bear the loading together at the beginning. The pile-soil stress ratio increased with increasing initial loading. The top of the pile gradually penetrated into the cushion, so the role of the pile was gradually revealed. This indicates that the stress concentration phenomenon appeared in the pile body (Fig. 9). The main loads

\section{FIG. 7}

SEM micrographs of samples of analyzed concretes: (a) bulk cement paste (7-day-old concrete), (b) bulk cement paste (28-day-old concrete), (c) paste-aggregate interface (7day-old concrete), and (d) paste-aggregate interface (28-day-old concrete). (a)

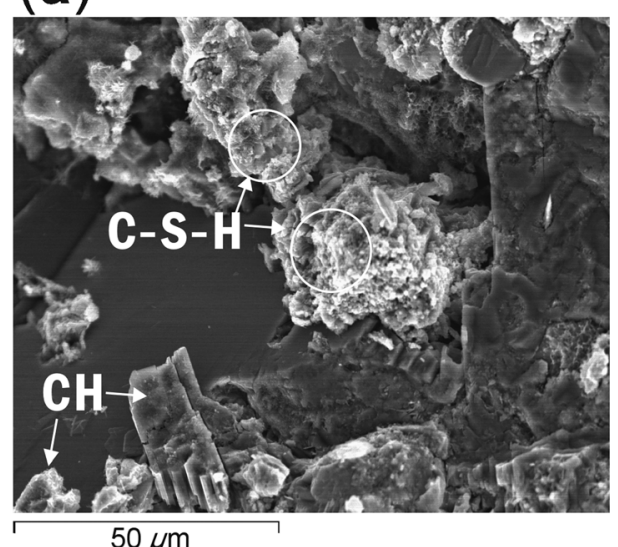

(c)

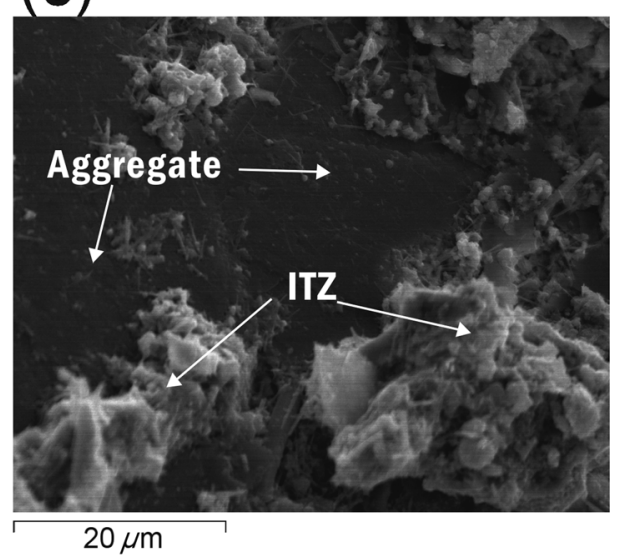

(b)

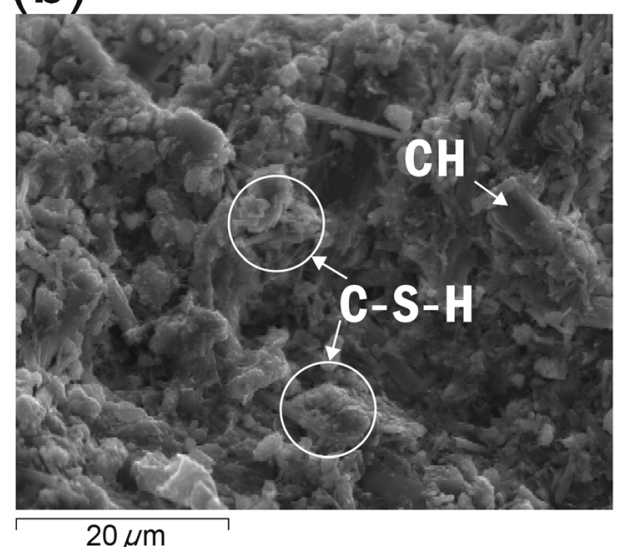

(d)

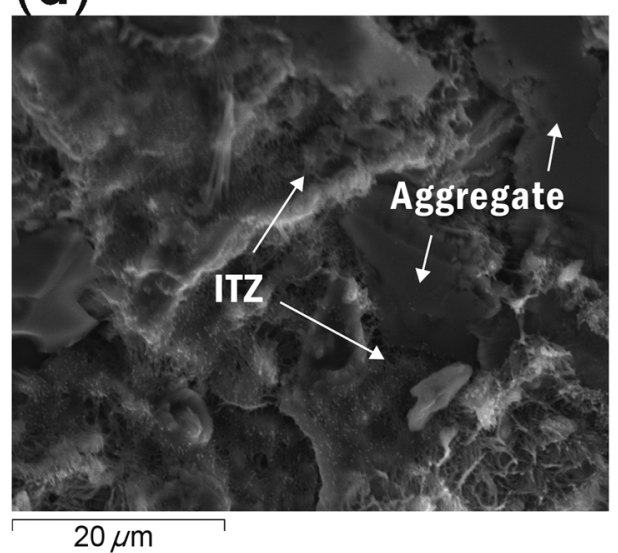


TABLE 3 The physical and mechanical properties of soil layers before and after consolidation.

\begin{tabular}{|c|c|c|c|c|c|c|c|c|c|c|c|}
\hline \multirow[b]{3}{*}{$\begin{array}{l}\text { Soil } \\
\text { Layer }\end{array}$} & \multirow[b]{3}{*}{ Conditions } & \multirow[b]{3}{*}{$\begin{array}{c}\text { Void } \\
\text { Ratio } \\
e\end{array}$} & \multirow[b]{3}{*}{$\begin{array}{c}\text { Plasticity } \\
\text { Index } \\
I_{p}\end{array}$} & \multirow[b]{3}{*}{$\begin{array}{c}\text { Compression } \\
\text { Modulus } \\
E_{s}(\mathrm{MPa})\end{array}$} & \multirow[b]{3}{*}{$\begin{array}{c}\text { Standard } \\
\text { Penetration } \\
\text { Number } N\end{array}$} & \multicolumn{6}{|c|}{ Strength Index } \\
\hline & & & & & & \multicolumn{2}{|l|}{$\begin{array}{l}\text { Direct } \\
\text { Shear }\end{array}$} & \multicolumn{2}{|c|}{$\begin{array}{c}\text { Triaxial Undrained } \\
\text { Shear }\end{array}$} & \multicolumn{2}{|c|}{$\begin{array}{c}\text { Triaxial Consolidation } \\
\text { Undrained Shear }\end{array}$} \\
\hline & & & & & & $\begin{array}{c}C \\
(\mathrm{kPa})\end{array}$ & $\begin{array}{l}\varphi \\
\left({ }^{\circ}\right)\end{array}$ & $\begin{array}{c}C_{u u} \\
(\mathrm{kPa})\end{array}$ & $\begin{array}{c}\varphi_{u u} \\
\left({ }^{\circ}\right)\end{array}$ & $\begin{array}{l}C_{c u} \\
(\mathrm{kPa})\end{array}$ & $\begin{array}{r}\varphi_{c u} \\
\left({ }^{\circ}\right)\end{array}$ \\
\hline \multirow[t]{2}{*}{ 1. Plain fill } & $\mathrm{BC}$ & 0.748 & 10 & 7.7 & 4.9 & 42.0 & 16.3 & 58.0 & 5.6 & 29.0 & 12.5 \\
\hline & $\mathrm{AC}$ & 0.68 & 9 & 7.7 & 8.5 & 52.9 & 20.0 & 71.4 & 4.1 & 44.8 & 23.17 \\
\hline \multirow[t]{2}{*}{ 2. Silty clay } & $\mathrm{BC}$ & 0.685 & 14 & 5.7 & - & 16.0 & 10.2 & 40.0 & 6.0 & 30.0 & 12.0 \\
\hline & $\mathrm{AC}$ & 0.61 & 16 & 10.03 & 9.1 & 29.6 & 20.0 & - & - & 53.2 & 30.1 \\
\hline \multirow[t]{2}{*}{ 3. Silty clay } & $\mathrm{BC}$ & 0.631 & 12 & 12.05 & 18.5 & 56.0 & 19.0 & 74.0 & 6.6 & 37.0 & 14.6 \\
\hline & $\mathrm{AC}$ & 0.62 & 13 & 16.5 & 14.6 & 72.0 & 25.6 & 106.3 & 5.9 & - & - \\
\hline
\end{tabular}

Note: $\mathrm{BC}=$ before consolidation; $\mathrm{AC}=$ after consolidation.

of the composite foundation taken by the soil were transferred to the pile. In the late period of loading, the pile-soil stress ratio in zone $\mathrm{B}$ rose slowly and began to decrease after reaching its maximum value. This indicated that plastic deformation was generated in the piles and that the load was gradually transferred back to the soil. The ratio in zone A, under the current load level, did not reach its maximum. However, as the load increased, the trend mentioned above became clearer.

\section{Variation of Load Distribution Ratio With Loading}

The load distribution over the pile $\delta_{p}\left(\delta_{p}=p_{p} / p\right)$ is defined as the percentage of the total load $p$ represented by the load $p_{p}$ born by the piles. The load distribution over the soil $\delta_{s}$ $\left(\delta_{s}=p_{s} / p\right)$ is the percentage of the total load $\mathrm{p}$ represented by the load $p_{s}$ born by the soil. Under a low level of load, the main load is born by the soil. With increasing load, the load distribution over the piles $\delta_{p}$ increases, and the corresponding load distribution over the soil $\delta_{s}$ decreases (Fig. 10). When the load

FIG. 8 Curve of displacement with load.

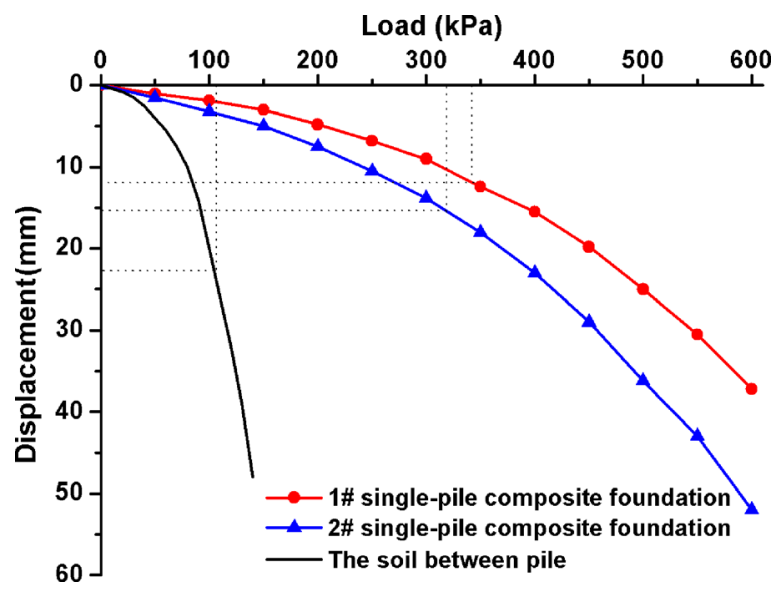

reaches approximately $420 \mathrm{kPa}$ in zone $\mathrm{B}$ and $750 \mathrm{kPa}$ in zone A, the load distribution over the piles and soil are equal. At this time, the load level is roughly equivalent to the proportional limit of the bearing capacity. With $\delta_{p}$ continuing to increase and $\delta_{s}$ continuing to decrease, the main load is shared by the piles. When $\delta_{p}$ reaches its maximum, plastic deformation has generated in the piles.

\section{Variation of Pile-Soil Stress Ratio With Replacement Ratio}

Under a low level of loading, the pile-soil stress ratios of two zones with different replacement ratios are similar. As the load increases, the growth rate of the pile-soil stress ratio in zone A is higher than that in zone $\mathrm{B}$, which is mainly because of the lower replacement rate in zone A (Fig. 9). Fig. 10 also shows the above rules from the perspective of the loading distribution. The load levels achieving $\delta_{p}=\delta_{s}$ in the composite foundation with a low replacement rate are lower than those in the composite foundation with a high replacement rate. Plastic deformation in the piles of the composite foundation with a low replacement rate is generated earlier than that with a high replacement rate.

\section{FIELD LOADING TEST RESULTS OF COMPOSITE FOUNDATION}

\section{Basement Settlement and Top Horizontal Displacement of Hand-Dug Pile}

The basement settlement is $24.0 \mathrm{~mm}$ after $1 \mathrm{~h}$, accounting for approximately $81 \%$ of the settlement on the 30th day (Fig. 11). The settlement is $28.93 \mathrm{~mm}$, which is almost stable approximately 3 days after the initiation of the field-loading test. The settlement is $29.64 \mathrm{~mm}$ after 30 days and shows a trend toward convergence. The horizontal displacement of the hand-dug pile top is $6.15 \mathrm{~mm}$ after $1 \mathrm{~h}$, which is equal to $82 \%$ of the displacement on the 30th day. The displacement after 3 days of loading 
FIG. 9

Curve of pile-soil stress ratio with load.

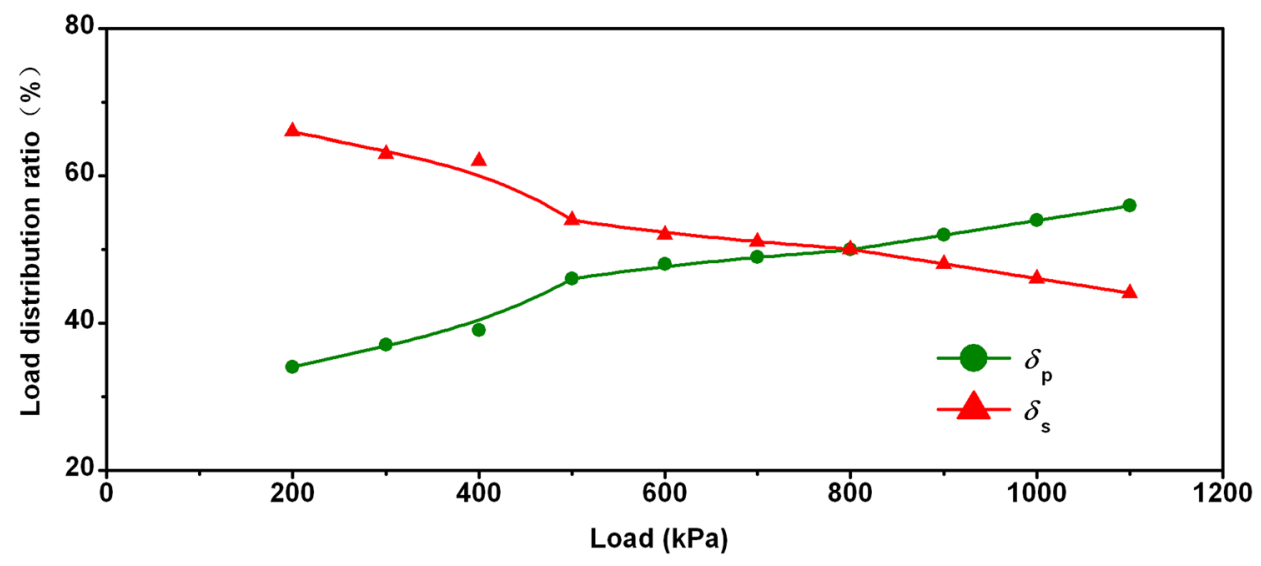

(a) $10.9 \%$ replacement rate (Zone A)

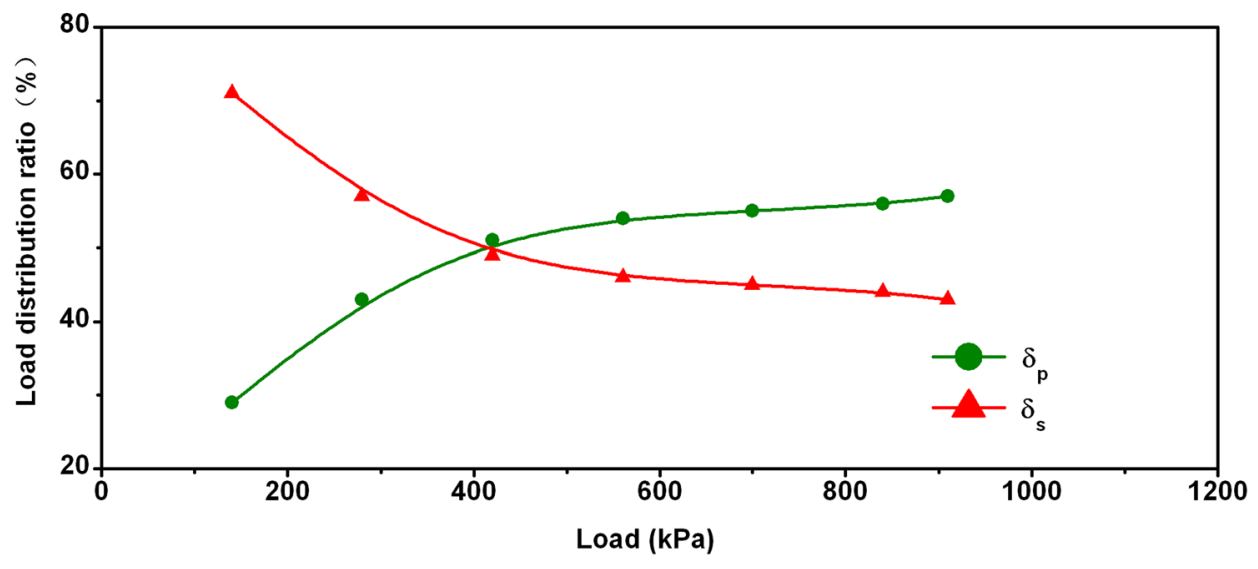

(b) $9.4 \%$ replacement rate (Zone B)

is $7.28 \mathrm{~mm}$, which is equal to $98 \%$ of the displacement on the 30th day. These findings indicate that the settlement of the composite foundation is effectively reduced and that the lateral deformation is limited.

FIG. 10 Curve of load distribution with load.

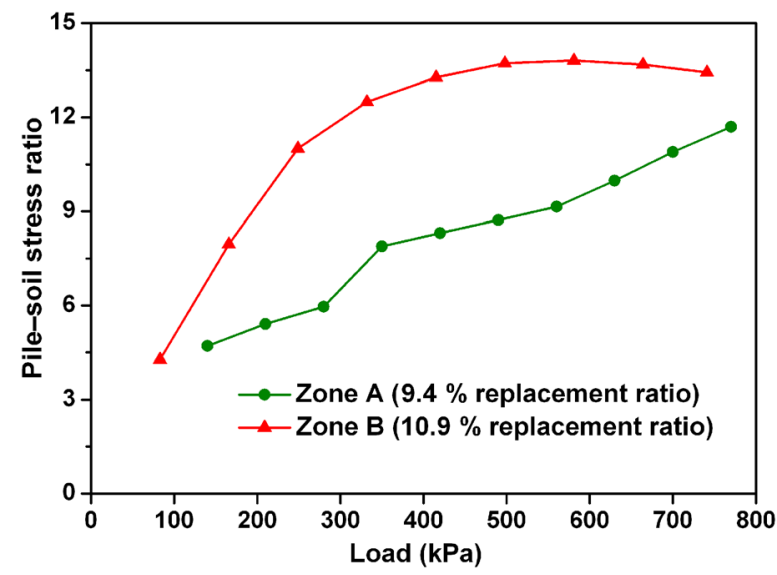

\section{Horizontal Displacement at Different Depths}

The horizontal displacements at different depths are measured by inclinometers. A negative value of the deep displacement means that the soil moves inward in the direction of the billet (Fig. 12). A positive value of the deep displacement means that

FIG. 11 Curve of settlement of foundation base-horizontal displacement of pile top at different times.

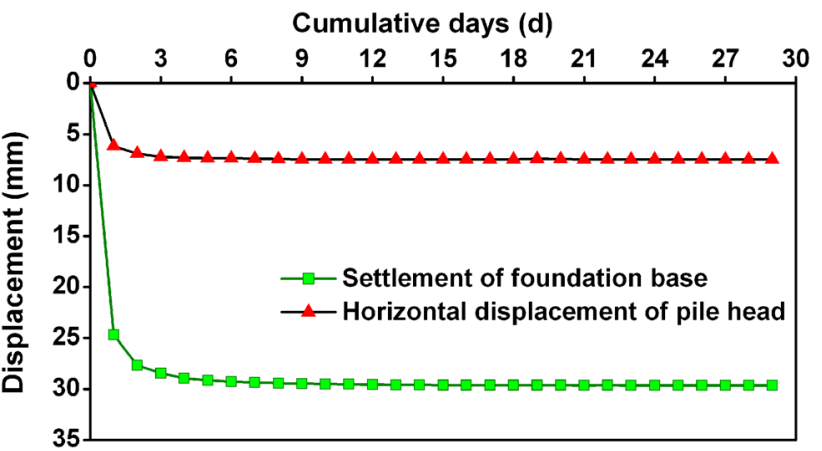


FIG. 12

The variable curve of horizontal displacement with depth

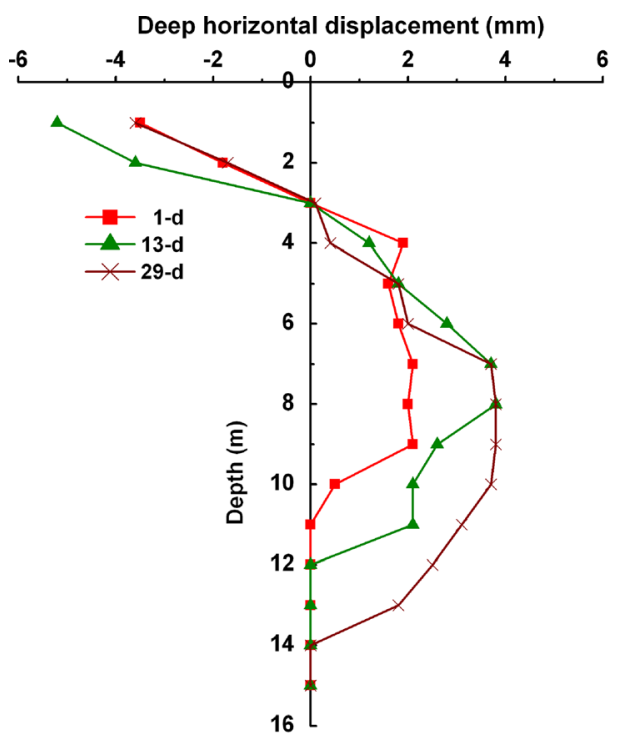

(a) Observation results of G1 hole (Long axis)
Deep horizontal displacement $(\mathrm{mm})$

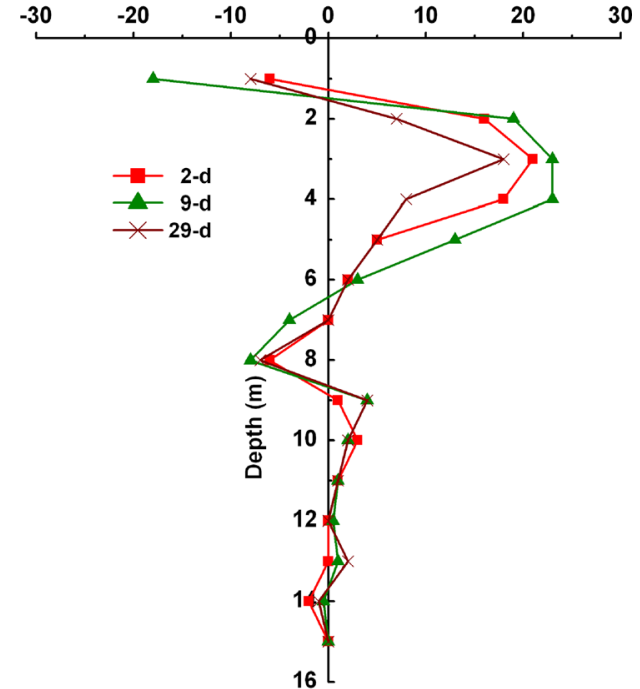

(b) Observation results of G2 hole (Short axis) the soil moves outward. Horizontal displacement observations suggest the following:

(1) Hole G1: Owing to the effect of loading, the medial soil is compacted and correspondingly sinking. The horizontal displacement within the depth of $3.0 \mathrm{~m}$ is negative. It is indicated that the shallow soil moves in the direction of the load. After 13 days, the maximum displacement is $-5.2 \mathrm{~mm}$ at a depth of $1.0 \mathrm{~m}$. Beneath the depth of $3.50 \mathrm{~m}$, the soil under billets is extruded outward, and its horizontal displacement is positive. The maximum displacement is $+4 \mathrm{~mm}$ between the depths of 6 to $9 \mathrm{~m}$. The horizontal displacement has the trend of convergence at the depth of $12 \mathrm{~m}$.

(2) Hole G2: The displacement within the depth of $1.50 \mathrm{~m}$ is negative. The maximum displacement observed on the 13th day is $-17.5 \mathrm{~mm}$. Beneath the depth of $1.50 \mathrm{~m}$, the horizontal displacement is outward and positive. The maximum is $+27.9 \mathrm{~mm}$ between the depths of 2 and $4 \mathrm{~m}$. In contrast, the horizontal displacement of short axial soil is significantly greater than that of long
FIG. 13

The variable curve of horizontal stress increase of the hand-dug pile with depth.
The increase of horizontal stress $(\mathrm{kPa})$

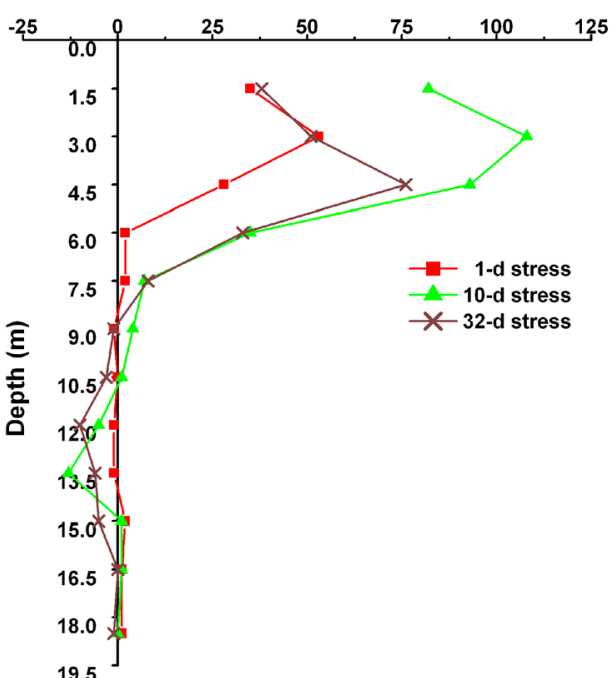

(a) The horizontal stress increase in the front of the hand-dug pile
The increase of horizontal stress $(\mathrm{kPa})$

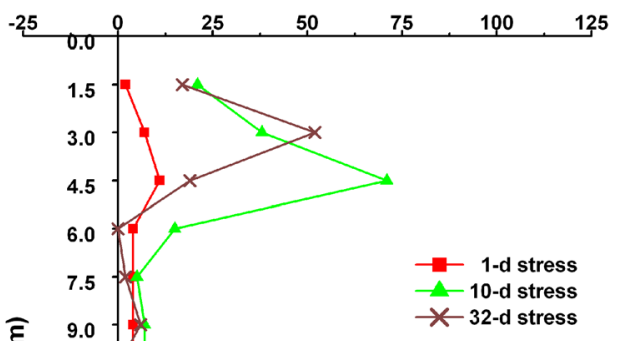


axis soil. An abnormal negative phenomenon can be observed in the segment between $7 \mathrm{~m}$ and $9 \mathrm{~m}$. This could be attributed to the influence of pile construction, that is, the soil compaction effect causes extrusion toward the load area, leading to negative displacement. The horizontal displacement has the trend of convergence at the depth of $10 \mathrm{~m}$.

The horizontal displacements in hole G1 and hole G2 indicate that the CFS pile composite foundation can effectively limit the lateral deformation.

\section{The Increase in Horizontal Stress of the Hand-Dug Pile}

The recorded data are used to discuss the extrusion effect of the hand-dug pile. The load has a significant influence on the stress within the soil around the pile (Fig. 13). The stress increase in the front of the hand-dug pile reaches its maximum $(117 \mathrm{kPa})$ at a depth of $3.0 \mathrm{~m}$. At a depth of $9.0 \mathrm{~m}$, the stress is $7 \mathrm{kPa}$, and the curve converges downward. It is indicated that the increase in stress in the horizontal direction has a significant effect at depths of less than $9.0 \mathrm{~m}$ and a negligible impact beneath that.

FIG. 14 The variable curve of vertical stress increase with depth.

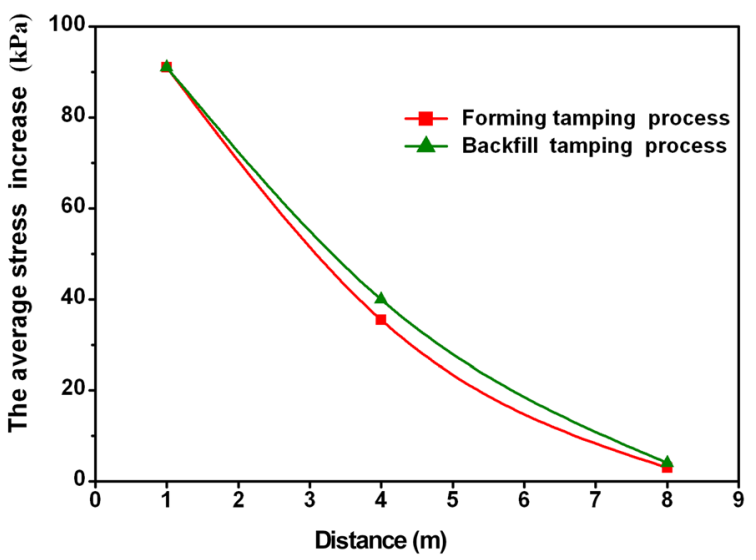

(a) Data of earth pressure sensors 1-3,2-3,3-2 (shallow part)

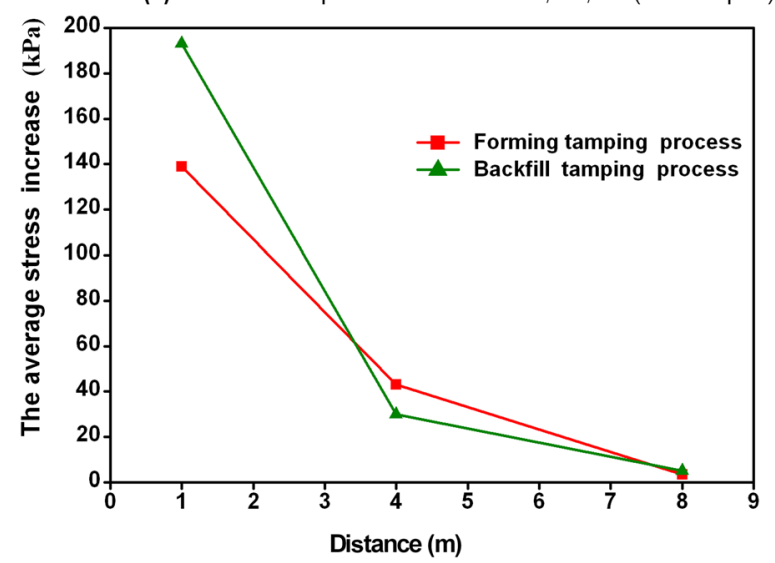

(b) Data of earth pressure sensors 1-4,2-4,3-3 (middle part)
FIG. 15 The variable curve of average increase of horizontal stress with distance.

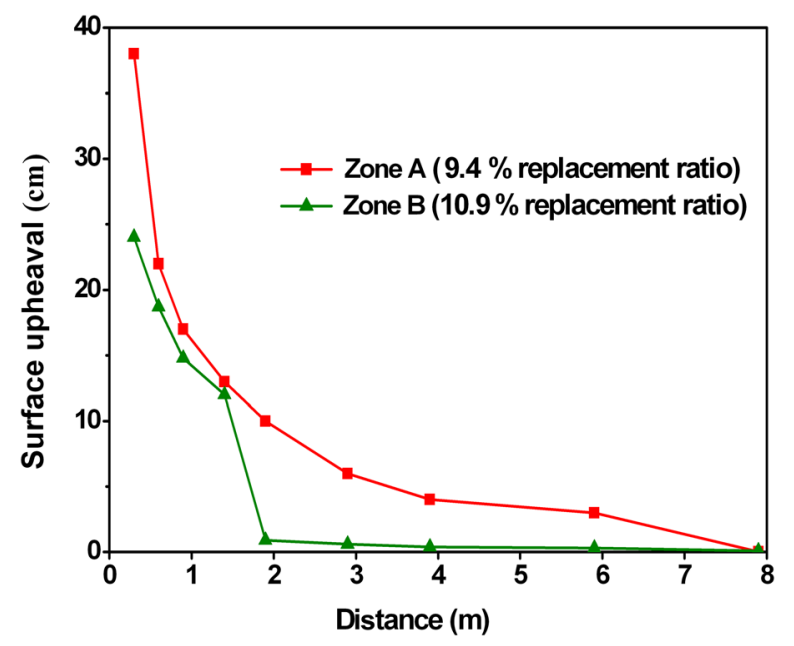

The increase in stress behind the hand-dug pile reaches a maximum $(63 \mathrm{kPa})$ at a depth of $4.5 \mathrm{~m}$. At the depth of $7.5 \mathrm{~m}$, the stress is $7 \mathrm{kPa}$, and the curve is converged downward. This shows that both the stress and the influence depth are smaller on the backside of the pile, which is possibly affected by the resistance of the hand-dug pile body itself. In addition, stress of the pile between 0 and $7.5 \mathrm{~m}$ has the following trends: stress was relatively small on the first day and then increased to the maximum $140 \mathrm{kPa}$ on the tenth day, and it decreased to $75 \mathrm{kPa}$ in the following 22 days. That is to say the CFS pile composite foundation can reduce the extrusion of the hand-dug pile caused by the superimposed pressure under the billet loads.

\section{Vertical Stress Increase in Soil Between Piles}

Earth pressure sensors are installed in the soil between the basement of the billet and the slag cushion layer according to the design depth to observe the variation of the increase in vertical stress at different depths under load. Fig. 14 shows that stress increase at a depth of $1.0 \mathrm{~m}$ under the billet base is the largest $(49 \mathrm{kPa})$. Faster convergence develops from the base to a depth of $4.8 \mathrm{~m}$, whereas slower convergence is found at depths below $4.8 \mathrm{~m}$. Under the loading effect, the soil area achieves a degree of consolidation, and the strength increases. Finally, after 28 days of loading, the measured values of the increase in stress decrease compared with that on the first day.

TABLE 4 The maximum stress increase with distance.

\begin{tabular}{lccr}
\hline Distance & $1.0 \mathrm{~m}$ & $4.0 \mathrm{~m}$ & $8.0 \mathrm{~m}$ \\
\hline Forming tamping process & $>300 \mathrm{kPa}$ & $60 \mathrm{kPa}$ & $10 \mathrm{kPa}$ \\
Backfill tamping process & $>300 \mathrm{kPa}$ & $50 \mathrm{kPa}$ & $6 \mathrm{kPa}$
\end{tabular}


FIG. 16 The variable curve of upheaval value with distance.

The increase in vertical stress $(\mathrm{kPa})$

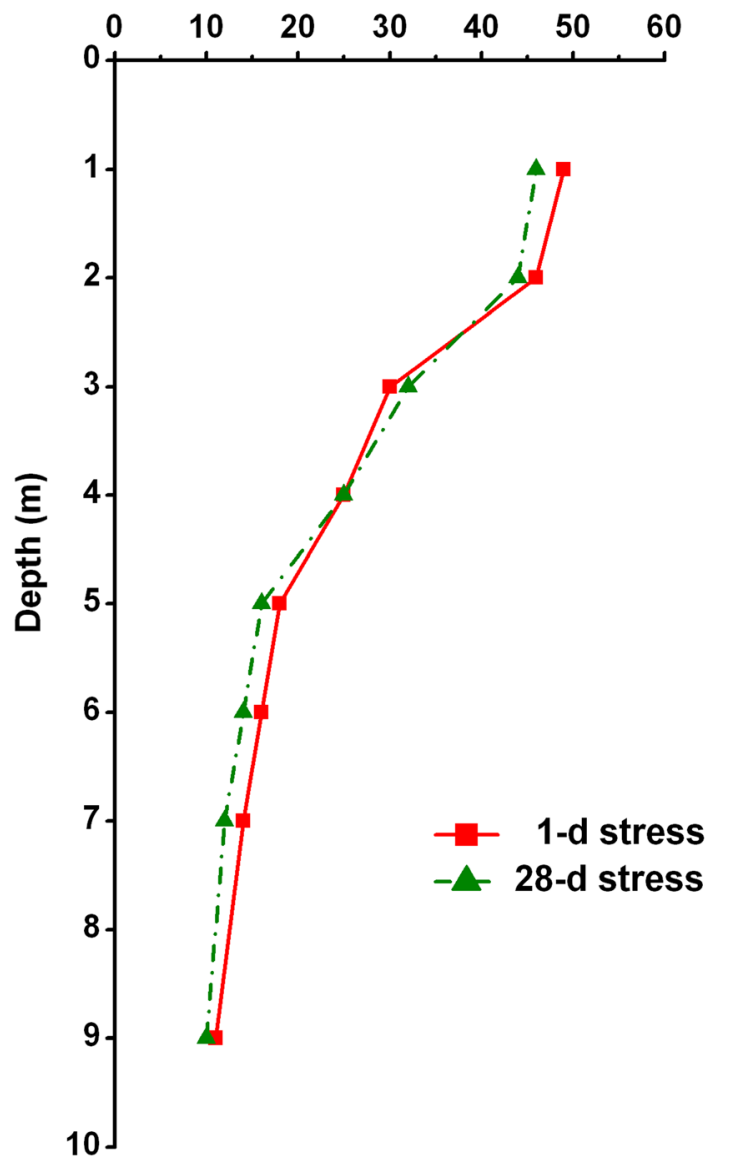

\section{SOIL SQUEEZING EFFECT RESULTS}

The maximum and average horizontal stress increase recorded by the earth pressure sensors in each case are studied using statistical analysis (Fig. 15 and Table 4).

The average stress increase in the horizontal direction and the measured maximum stress increase show the significant effect of soil squeezing within $1.0 \mathrm{~m}$ of the center of the CFS pile. The stress increase in this area is also the largest, whose maximum value is more than $300 \mathrm{kPa}$. With an increasing distance, the value decreases significantly in the range of $0 \mathrm{~m}$ to $4.0 \mathrm{~m}$. If the distance continues to increase, the curve dips, and thus there is no squeezing effect beyond $8.0 \mathrm{~m}$. The central average stress increase is relatively larger than the shallow and deep increase. Fig. 16 shows that the largest amount of surface upheaval is $38 \mathrm{~cm}$ at a distance of $0.3 \mathrm{~m}$ from the center of the CFS pile. The upheaval quickly decays with increasing distance and become stable $2.0 \mathrm{~m}$ from the center of the pile. At $7.9 \mathrm{~m}$, the upheaval quantity is only $1 \mathrm{~cm}$ to $3 \mathrm{~cm}$. The upheaval of zone $\mathrm{A}$ is greater than that of zone $\mathrm{B}$ owing to a larger replacement rate. The soil squeezing effect results provide a reference for the design of pile spacing and arrangements.

\section{Conclusions}

The recycling of steel slag in composite foundations can reduce the environmental pollution caused by the deposition of steel slag. Moreover, the application of recycled steel slag to the composition of foundations also has great economic value. This study investigates the recycling of steel slag as an aggregate for piles used in composite foundations for ground improvement. The results prove that the use of steel slag has a positive effect on the ground improvement and bearing characteristics of composite pile foundations. Detailed conclusions can be drawn as follows.

(1) The micromechanisms of CFS piles are revealed by SEM micrographs. The dense microstructures of intimate intermingling of C-S-H gels and better bonding between the hydration products and the surface of the aggregates are suggested to be the critical factors in the development of strength for good macroscopic mechanical properties.

(2) The CFS pile composite foundation has proven to be an effective method for improving the bearing capacity of underlying soft ground. The physical and mechanical properties of the soil around the composite foundation demonstrate significant improvement. It is observed that the loading is rearranged to be distributed between the piles and the soil according to the pile-soil stress ratio. This indicates that the bearing capacity of the piles and subsoil are well mobilized. The results of the large area pile-loading test show that both the settlement of the composite foundation and the horizontal displacement of the top of the hand-dug pile are small. The horizontal displacements of the composite foundation at different depths and the increase in stress of the hand-dug pile indicate that the CFS pile composite foundation can effectively limit the horizontal deformation.

(3) The stress monitoring results indicate that the stress increase in the CFS pile composite foundation is dissipated significantly and tends to be uniformly distributed. The influence range caused by the increase in the stress of the soil around the piles and the amount of surface upheaval during the construction process are obtained from the soil squeezing effect test results, which provide a reference for the design of pile spacing and arrangements.

(4) However, steel slag may have significant environmental concern as it contains some toxic substances that will leach to ground water. So it is essential to do further research on the ground water contamination caused by CFS pile composite foundation.

\section{ACKNOWLEDGMENTS}

This project is supported by the National Natural Science Foundation of China (Grant Nos. 41572301, 41330634) and the 
Fundamental Research Funds for the Central Universities of China (Grant Nos. 2-9-2012-105, 2-9-2015-071). The writers appreciate the financial support of the organizations. Additionally, the writers thank Mr. Huang Tao at Wuhan Surveying Geotechnical Research Institute Co., Ltd. of MCC for his help during the experimental work.

\section{References}

[1] Wu, S., Xue, Y., Ye, Q., and Chen, Y., "Utilization of SteelSlag as Aggregates for Stone Mastic Asphalt (SMA) Mixtures," Build. Environ., Vol. 42, 2007, pp. 2580-2585 (in Chinese).

[2] Lun, Y., Zhou, M., and Chen, M., "Volume Stability and Application Prospect of Steel-Slag Aggregates in Engineering," Express Inf. Mining Ind., No. 4, 2006, pp. 37-40 (in Chinese).

[3] Geiseler, J., "Use of Steelworks Slag in Europe," Waste Manage., Vol. 16, Nos. 1-3, 1996, pp. 59-63.

[4] Dimitrova, S. V. and Mehanjiev, D. R., "Interaction of Blast-Furnace Slag With Heavy Metal Ions in Water Solutions," Water Res., Vol. 34, No. 6, 2000, pp. 1957-1961.

[5] Das, B., Prakash, S., Reddy, P. S., and Misra, V. N., "An Overview of Utilization of Slag and Sludge From Steel Industries," Res., Conserv. Recyc., Vol. 50, No. 1, 2007, pp. $40-57$.

[6] Aiban, S. A., "Utilization of Steel-Slag Aggregate for Road Bases," J. Test. Eval., Vol. 34, No. 1, 2006, pp. 65-76.

[7] Haritonovs, V., Zaumanis, M., Brencis, G., and Smirnovs, J., "Performance Characterization of Bituminous Mixtures With Dolomite Sand Waste and BOF Steel-Slag," J. Test. Eval., Vol. 40, No. 7, 2012, pp. 1-6.

[8] Chen, S. H., Lin, J. D., Huang, D., and Hung, C. T., "Effect of Film Thickness and Voids in Mineral Aggregate in Basic Oxygen Furnace Slag Dense-Graded Asphalt Concrete," J. Test. Eval., Vol. 43, No. 2, 2015, pp. 229-236.

[9] Shi, H., Huang, K., Wu, K., and Guo, X., "Research Advance on Activation and Mechanism of Steel-Slag Activity," Fly Ash Comprehens. Util., No. 1, 2011, pp. 48-53 (in Chinese).

[10] Wang, Q., Yan, P., and Han, P., "The Influence of Steel-Slag on the Hydration of Cement during the Hydration Process of Complex Binder," Sci. China Technol. Sci., Vol. 54, No. 2, 2007, pp. 388-394 (in Chinese).

[11] Xue, Y., Wu, S., Hou, H., and Zha, J., "Experimental Investigation of Basic Oxygen Furnace Slag Used as Aggregate in Asphalt Mixture," J. Hazard. Mater., Vol. 138, No. 2, 2006, pp. 261-268 (in Chinese).

[12] Beshr, H., Almusallam, A. A., and Maslehuddin, M., "Effect of Coarse Aggregate Quality on the Mechanical Properties of High Strength Concrete," Constr. Build. Mater., Vol. 17, No. 2, 2003, pp. 97-103.

[13] Tsakiridis, P. E., Papadimitriou, G. D., Tsivilis, S., and Koroneos, C., "Utilization of Steel-Slag for Portland Cement Clinker Production," J. Hazard. Mater., Vol. 152, No. 2, 2008, pp. 805-811.
[14] Wang, B. L., Wu, B. Y., and Fang, W. M., "Research on Foundation Consolidation by Steel-Slag Pile," J. Shanghai Inst. Railway Technol., Vol. 15, No. 1, 1994, pp. 77-84 (in Chinese).

[15] Chen, Q. N., Zhao, M. H., and Zhou, G. H., "Bearing Capacity and Mechanical Behavior of CFG Pile Composite Foundation," J. Central South Univ. Technol., Vol. 15, No. 2, 2008, pp. 45-49 (in Chinese).

[16] Maslehuddin, M., Alfarabi, M., Sharif, M., and Shameem, M., "Comparison of Properties of Steel-Slag and Crushed Limestone Aggregate Concretes," Constr. Build. Mater., Vol. 17, No. 2, 2003, pp. 105-112.

[17] Huang, T., Wang, X. Z., Wu, Y. G., and Chen, C. J., "Experimental Research and Application of Composite Ground of Steel-Ash Pile Within a Steel Factory in North Henan Province," Chinese J. Geotechnical Eng., Vol. 21, No. 3, 1999, pp. 328-333 (in Chinese).

[18] Zhou, S. C. and Du, K. Q., "Experimental Investigation of Subgrade Treatment by CFS Piles," Soil Eng. Found., Vol. 16, No. 1, 2002, pp. 9-11 (in Chinese).

[19] Tong, J. X., Hu, Z. J., and Yan, M. L., "Identification of the Bearing Capacity of CFG Pile Composite Foundation," China Civil Eng. J., Vol. 38, No. 7, 2005, pp. 87-91 (in Chinese).

[20] Ahmaruzzaman, M., "A Review on the Utilization of Fly Ash,” Prog. Energy Combust. Sci., Vol. 36, No. 3, 2010, pp. 327-363.

[21] Zhang, L., Ahmari, S., and Zhang, J., "Synthesis and Characterization of Fly Ash Modified Mine Tailings-Based Geopolymers," Constr. Build. Mater., Vol. 25, No. 9, 2011, pp. 3773-3781.

[22] Shan, Z. F., "The State of Treatment Technique and Comprehensive Utilization to Steel-Slag in China and Abroad," Indust. Safety Dust Contr., No. 2, 2000, pp. 27-32 (in Chinese).

[23] Zhan, C. H., Liao, J. L., and Ju, J. T., "Treatment Process and Utilization Technology of Steel-slag in China and Abroad," J. Iron Steel Res., Vol. 25, No. 7, 2013, pp. 1-4 (in Chinese).

[24] GB/T 50107-2010, "Standard for Evaluation of Concrete Compressive Strength," China Architecture and Building Press, Beijing, China, 2010 (in Chinese).

[25] Moser, R. D., Allison, P. G., and Chandler, M. Q., "Characterization of Impact Damage in Ultra-High Performance Concrete Using Spatially Correlated Nan Indentation/SEM/EDX," J. Mater. Eng. Perform., Vol. 22, No. 12, 2013, pp. 3902-3908.

[26] Wang, D., Abriak, N. E., and Zentar, R., "Strength and Deformation Properties of Dunkirk Marine Sediments Solidified With Cement, Lime and Fly Ash," Eng. Geol., Vol. 166, 2013, pp. 90-99.

[27] Diamond, S. and Huang, J., "The ITZ in Concrete-A Different View Based on Image Analysis and SEM Observations," Cement Concrete Compos., Vol. 23, No. 2, 2001, pp. 179-188.

[28] Golewski, G. L. and Sadowski, T., "An Analysis of Shear Fracture Toughness KIIc and Microstructure in Concretes Containing Fly-Ash," Constr. Build. Mater., Vol. 51, 2014, pp. 207-214. 
[29] Mouret, M., Bascoul, A., and Escadeillas, G., "Microstructural Features of Concrete in Relation to Initial Temperature-SEM and ESEM Characterization," Cement Concrete Res., Vol. 29, No. 3, 1999, pp. 369-375.

[30] Wang, S., Baxter, L., and Fonseca, F., "Biomass Fly Ash in Concrete: SEM, EDX and ESEM Analysis," Fuel, Vol. 87, No. 3, 2008, pp. 372-379.

[31] Peethamparan, S., Olek, J., and Lovell, J., "Influence of Chemical and Physical Characteristics of Cement Kiln Dusts (CKDs) on their Hydration Behavior and Potential Suitability for Soil Stabilization," Cement Concrete Res., Vol. 38, No. 6, 2008, pp. 803-815.
[32] Xia, C., Jianjun, Y., and Huaguan, Y., "Influence of Aggregates on Cracking Sensitivity of Concrete," Appl. Mech. Mater., Vol. 204, 2012, pp. 3299-3302.

[33] Beaudoin, J. J., Gu, P., and Myers, R. E., "The Fracture of C-S-H and C-S-H/CH Mixtures," Cement Concrete Res., Vol. 28, No. 3, 1998, pp. 341-347.

[34] Ma, S., "Test on Pile-Soil Stress Ratio of Composite Foundation With Cement-Soil Pile," China Civil Eng. J., Vol. 35, No. 2, 2002, pp. 48-51 (in Chinese).

[35] JGJ79-2012, "Technical Code for Ground Treatment of Buildings," China Architecture and Building, Beijing, China, 2012 (in Chinese). 